\title{
Physical and Mechanical Properties of Metamorphic Rocks
}

\author{
Zozk Kawa Abdaqadir ${ }^{1 *}$ Younis Mustafa Alshkane $^{2}$ \\ ${ }^{1}$ Civil Engineering Department, College of Engineering, University of Sulaimani, \\ Al- Sulaimaniyah, Kurdistan Region, Iraq \\ ${ }^{2}$ Civil Engineering Department, College of Engineering, University of Sulaimani, \\ Al- Sulaimaniyah, Kurdistan Region, Iraq \\ Email: younis.ali@univsul.edu.iq \\ *Corresponding author. Email: Zozk.abdalqadir@univsul.edu.iq
}

\begin{abstract}
In this study, the relationships between the physical and mechanical properties of metamorphic rocks have been investigated based on data that were collected from previous studies. The data for the physical and mechanical properties of metamorphic rocks such as (Density, Young's modulus, Uniaxial Compressive Strength (UCS), Porosity, Tensile strength, Specific Gravity) for some types of metamorphic rocks ( Gneiss, Schist, Phyllite, Slate, Marble, Amphibolite, Hornfels and Quartzite) were collected from previous studies. The statistical analysis has been investigated in order to find the valuable relationships between physical and mechanical properties of the studied rock.. The results revealed linear relationships between those properties. Based on the coefficient of determination $\left(\mathrm{R}^{2}\right)$, the best linear correlations were obtained between Young's modulus and Porosity with $\mathrm{R}^{2}$ of 0.86 whereas, the weak relationship was found between UCS and Specific Gravity of $R^{2}=0.22$. This indicates that there is not a direct relationship between UCS and specific gravity.
\end{abstract}

Keywords: Metamorphic rocks; UCS; porosity; specific gravity; Physical Properties; Mechanical Properties.

\section{Introduction}

Metamorphic rocks are the rocks that formed from other rocks. They are sedimentary rocks or pyrotechnics that have changed due to extreme pressure and heat. The configured name defines where "meta" means change and "morph" means "form". Thus, mutated rocks are those whose shapes have been altered through a geological process 
such as large tectonic movements and magma penetrations. Transient transformation occurs mainly due to changes in temperature; pressure exerted, and the introduction of chemically active fluids. For metamorphism to occur, there are some conditions which speed up the process that is the geologic events that happen on large scales such as the movement of the global lithospheric plate, the seduction of the lithosphere of the ocean, the collision of the continents and the spreading of the ocean floor. All the mentioned three have the consequence of rocks that are moving transport heat; these changes in pressure and temperature are the important variables in the changes in the rock texture (Owaid et al., 2015). In the North East corner of Arabia, Peninsula lays the country of Iraq. The country island to different contrasting geography that consists of the arid desert in the west of mountains that are rugged of Taurus and Zagros in the northeast; the two regions are separated by the fertile depression of Mesopotamia. In geology, Iraq is said to lie in the transition between the Arabian Shelf and the damaged areas of Taurus and Zagros Zones in the North and North East (Al-Juboury et al., 2009).

The design of underground structures such as road tunnels and rail tunnels depends on the data collected through the physical and mechanical properties of the rocks. These geotechnical properties of rocks play an important role in design, safety, stability and rock structures when they are exposed to heterogeneous areas in situ resulting from excess stresses, tectonicity and gravity, which are locally complicated by water pressure and pressure, Persuaded by the excavations. The physical and mechanical parameters play a very important role in a precise forecast of rock behavior under such inconsistent conditions. The mechanical properties of rocks change with density, porosity, UCS, specific gravity, grain size, texture and effective pressures acting on them. Changes in physical and mechanical properties in metamorphic rocks lead to corresponding variations in failure pattern (Singh et al., 2017). In this study, the linear relationships between physical and mechanical properties of metamorphic rocks were investigated based on data collected from the previous studies.

\section{Objective}

This study aimed to investigate the correlations between the physical and mechanical properties of metamorphic rocks.

\section{Materials and Methods}

\subsection{Materials}


In this study based on literature different types of metamorphic rocks such as (gneiss, phyllite, schist, slate, hornfels, marble, quartzite, novaculite and amphibolite) were used for the correlation between the physical and mechanical properties of metamorphic rocks.

\subsection{Methods}

Based on previous studies for the physical and mechanical properties of metamorphic rocks such as (Young's modulus, E), (Density, $\rho$ ), (Uniaxial compressive strength, UCS), (Porosity, n), (Tensile Strength, $\sigma \mathrm{t}$ ), (Specific Gravity, Gs) data were collected as summarized in Table (1). and the correlation between those properties were conducted.

Table 1: Literature Review for the Physical and Mechanical Properties of Metamorphic Rocks

\begin{tabular}{|c|c|c|c|c|c|c|c|}
\hline \multirow[b]{2}{*}{ Reference } & \multirow[b]{2}{*}{ Location } & \multicolumn{6}{|c|}{ Number of data collected from previous studies } \\
\hline & & $\begin{array}{c}\text { Density } \\
\rho \\
\left(\mathrm{g} / \mathrm{cm}^{3}\right)\end{array}$ & $\begin{array}{l}\text { Young's } \\
\text { modulus } \\
\text { E (GPa) }\end{array}$ & $\begin{array}{c}\text { UCS } \\
\text { (MPa) }\end{array}$ & $\begin{array}{c}\text { Porosity } \\
\text { n (\%) }\end{array}$ & $\begin{array}{c}\text { Tensile } \\
\text { strength } \\
\sigma t(\mathrm{MPa})\end{array}$ & $\begin{array}{c}\text { Specific } \\
\text { Gravity } \\
\text { Gs }\end{array}$ \\
\hline Ozcelik, (2011) & Turkey & - & - & 16 & - & 16 & - \\
\hline Jayawardena, (2011) & Sri Lanka & - & - & 14 & - & 14 & - \\
\hline Siegesmund et al., (2011) & Germany & 27 & 13 & - & 27 & 13 & - \\
\hline Kahraman et al., (2012) & Turkey & - & - & 15 & - & 15 & - \\
\hline Tandon et al., (2013) & India & 42 & - & 42 & - & - & - \\
\hline Benayad et al., (2013) & Korea & & & & & & \\
\hline Perras et al., (2014) & Switzerland & - & - & 6 & - & - & - \\
\hline Talabi et al., (2014) & Nigeria & - & - & 22 & 22 & - & 22 \\
\hline Barros et al., (2014) & Portugal & 5 & - & - & 5 & - & - \\
\hline Gholami et al., (2014) & Malaysia & 3 & - & - & 3 & 14 & - \\
\hline Khanlari et al., (2014) & Iran & 6 & - & - & 6 & - & 6 \\
\hline El-Hamid et al., (2015) & Egypt & 3 & - & 3 & 3 & - & - \\
\hline Mustafa et al., (2015) & Pakistan & - & - & 10 & - & 10 & - \\
\hline Gegenhuber, (2016) & Australia & 12 & - & - & 12 & - & - \\
\hline Chen et al., (2016) & China & 35 & - & - & 35 & - & - \\
\hline Fereidooni, (2016) & Iran & 8 & 8 & 8 & 8 & - & - \\
\hline Singh et al., (2017) & India & 3 & 3 & 3 & 3 & 3 & 3 \\
\hline Udagedara et al., (2017) & Sri Lanka & 5 & - & 5 & 5 & - & 5 \\
\hline Motra et al., (2017) & Germany & 28 & 28 & - & - & - & - \\
\hline Su et al., (2017) & USA & - & 9 & - & - & 9 & - \\
\hline Mishra et al., (2017) & India & - & 11 & - & - & - & - \\
\hline Özbek et al., (2018) & Turkey & 4 & - & - & 4 & - & - \\
\hline
\end{tabular}




\section{Results and discussions}

\subsection{Physical and mechanical properties}

\subsubsection{Density $(\rho)\left(\mathrm{g} / \mathrm{cm}^{3}\right)$}

The density of the metamorphic rocks as summarized in Table 1. Based on total of 181 data varied from 2.04 to $3.29 \mathrm{~g} / \mathrm{cm}^{3}$ with a mean of 2.71 , the standard deviation of 0.20 , variance of 0.04 , median of 2.7 and the coefficient of variation (C.O.V) of 7.35 as summarized in Table 2.

\subsubsection{Young's modulus, E (GPa)}

The young's modulus of the metamorphic rocks as summarized in Table 1. Based on total of 72 data varied from 10.44 to $217.44 \mathrm{GPa}$, with a mean of 74.22 , standard deviation of 48.75 , variance of 2377 , median of 58.7 and the coefficient of variation (C.O.V) of 65.7 as summarized in Table 2.

\subsubsection{Uniaxial compressive strength (UCS), (MPa)}

The uniaxial compressive strength of the metamorphic rocks as summarized in Table 1. Based on total of 169 data varied from 8 to $355 \mathrm{MPa}$, with a mean of 104, standard deviation of 62.10 , variance of 3857 , median of 96 and the coefficient of variation (C.O.V) of 60 as summarized in Table 2.

\subsubsection{Porosity (n), (\%)}

The porosity of the metamorphic rocks as summarized in Table 1. Based on total of 182 data varied from $0.02-10.95 \%$, with a mean of 3.1, standard deviation of 3.14, variance of 9.9, median of 1.9 and the coefficient of variation (C.O.V) of 101 as summarized in Table 2.

\subsubsection{Tensile strength $(\sigma \mathrm{t})$, (MPa)}

The tensile strength of the metamorphic rocks as summarized in Table 1. Based on total of 78 data varied from 2.3 to $18.1 \mathrm{MPa}$, with a mean of 8.61, standard deviation of 3.68 , variance of 13.52, median of 8.35 and the coefficient of variation (C.O.V) of 43 as summarized in Table 2.

\subsubsection{Specific Gravity, Gs}

The specific Gravity of the metamorphic rocks as summarized in Table 1. Based on the total of 36 data varied from 1.72 to 2.84 with a mean of 2.61, the standard deviation of 0.26 , variance of 0.068 , median of 2.68 and the coefficient of variation (C.O.V) of 10 as summarized in Table 2.

\subsection{Correlation between Physical and mechanical properties}

Based on the collected data from previous for physical and mechanical properties for metamorphic rocks statistical analysis were studied as summarized in Table 2 and 13 
linear relationships between those properties were investigated as presented in Table 3 . And the graph for each relationships as shown in Fig. 1,2,3,4,5,6,7,8,9,10,11,12 and 13.

Table 2 Statistical Analysis for Metamorphic Rocks

\begin{tabular}{|l|c|c|c|c|c|c|}
\hline \multicolumn{1}{|c|}{$\begin{array}{c}\text { Statistical } \\
\text { Parameters }\end{array}$} & Density & $\begin{array}{c}\text { Young's } \\
\text { modulus }\end{array}$ & UCS & Porosity & $\begin{array}{c}\text { Tensile } \\
\text { strength }\end{array}$ & $\begin{array}{c}\text { Specific } \\
\text { Gravity }\end{array}$ \\
\hline Range( Min,Max) & $2.04-3.29$ & $\begin{array}{c}10.45- \\
217.50\end{array}$ & $8-355$ & $\begin{array}{c}0.02- \\
10.95\end{array}$ & $2.3-18.1$ & $1.72-2.84$ \\
\hline Mean & 2.71 & 74.22 & 104 & 3.1 & 8.61 & 2.61 \\
\hline Std. Deviation & 0.20 & 48.75 & 62.10 & 3.14 & 3.68 & 0.26 \\
\hline Median & 2.7 & 58.7 & 96 & 1.9 & 8.35 & 2.68 \\
\hline Variance & 0.04 & 2377 & 3857 & 9.9 & 13.52 & 0.068 \\
\hline C.O.V (\%) & 7.35 & 65.7 & 60 & 101 & 43 & 10 \\
\hline No. of Data & 181 & 72 & 169 & 182 & 78 & 36 \\
\hline
\end{tabular}

Table 3 Summary of Correlations between Physical and Mechanical Properties of Metamorphic Rocks

\begin{tabular}{|c|c|c|c|c|c|c|}
\hline No. & Dependent variables & Independent variables & Equations & $\mathrm{R}^{2}$ & $\begin{array}{c}\text { No. } \\
\text { of } \\
\text { Data }\end{array}$ & $\begin{array}{l}\text { No } \\
\text { of } \\
\text { graph }\end{array}$ \\
\hline 1 & Density, $\rho\left(\mathrm{g} / \mathrm{cm}^{3}\right)$ & Young's modulus, E (GPa) & $E=189.41 \rho-460.65$ & 0.77 & 68 & 1 \\
\hline 2 & Density, $\rho\left(\mathrm{g} / \mathrm{cm}^{3}\right)$ & UCS (MPa) & $\mathrm{UCS}=179 \rho-394.38$ & 0.30 & 138 & 2 \\
\hline 3 & Density, $\rho\left(\mathrm{g} / \mathrm{cm}^{3}\right)$ & Porosity,n (\%) & $\mathrm{N}=-6.9915 \rho+20.159$ & 0.58 & 90 & 3 \\
\hline 4 & Density, $\rho\left(\mathrm{g} / \mathrm{cm}^{3}\right)$ & Tensile strength (MPa) & $\sigma \mathrm{t}=15.616 \rho-35.261$ & 0.83 & 54 & 4 \\
\hline 5 & Tensile strength (MPa) & UCS (MPa) & $\mathrm{UCS}=10.847 \sigma \mathrm{t}+10.841$ & 0.71 & 70 & 5 \\
\hline 6 & Tensile strength (MPa) & Young's modulus, E (GPa) & $\mathrm{E}=4.3448 \sigma \mathrm{t}+0.4039$ & 0.66 & 47 & 6 \\
\hline 7 & $\begin{array}{l}\text { Young's modulus , E } \\
\text { (GPa) }\end{array}$ & UCS (MPa) & $\mathrm{UCS}=0.9437 \mathrm{E}+31.621$ & 0.72 & 72 & 7 \\
\hline 8 & Density, $\rho\left(\mathrm{g} / \mathrm{cm}^{3}\right)$ & $\begin{array}{l}\text { Young's modulus/Tensile } \\
\text { strength }\end{array}$ & $\mathrm{E} / \sigma_{\mathrm{t}}=$ & 0.78 & 52 & 8 \\
\hline 9 & $\begin{array}{l}\text { Young's modulus , E } \\
(\mathrm{GPa})\end{array}$ & Porosity, n (\%) & $\mathrm{n}=-0.0047 \mathrm{E}+0.951$ & 0.86 & 58 & 9 \\
\hline 10 & Specific Gravity, Gs & Density, $\rho(\mathrm{g} / \mathrm{cm} 3)$ & $\rho=1.5366$ Gs -1.4632 & 0.54 & 33 & 10 \\
\hline 11 & UCS (MPa) & Specific Gravity, Gs & $\begin{array}{l}\text { Gs }==-0.0004 \text { UCS }+ \\
2.743\end{array}$ & 0.22 & 32 & 11 \\
\hline 12 & Tensile strength (MPa) & Specific Gravity, Gs & $\mathrm{Gs}=0.0049 \sigma \mathrm{t}+2.6401$ & 0.48 & 36 & 12 \\
\hline 13 & UCS (MPa) & $\begin{array}{l}\text { Young's modulus / } \\
\text { Density }\end{array}$ & $\begin{array}{l}E / \rho=0.1602 \text { UCS }+ \\
8.5131\end{array}$ & 0.60 & 72 & 13 \\
\hline
\end{tabular}




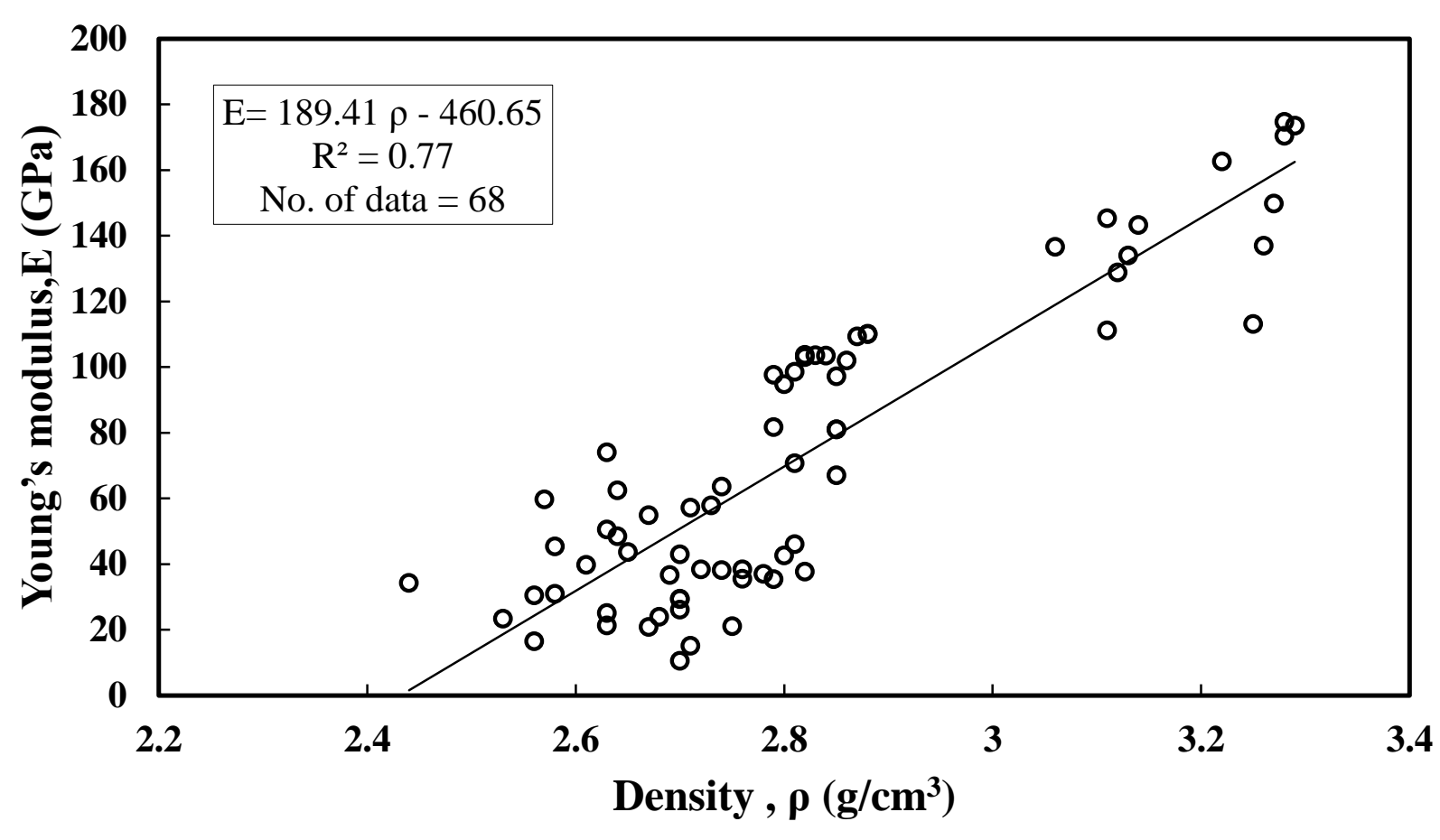

1 linear variation between density $(\rho)$ and Young's modulus (E)

Fig.

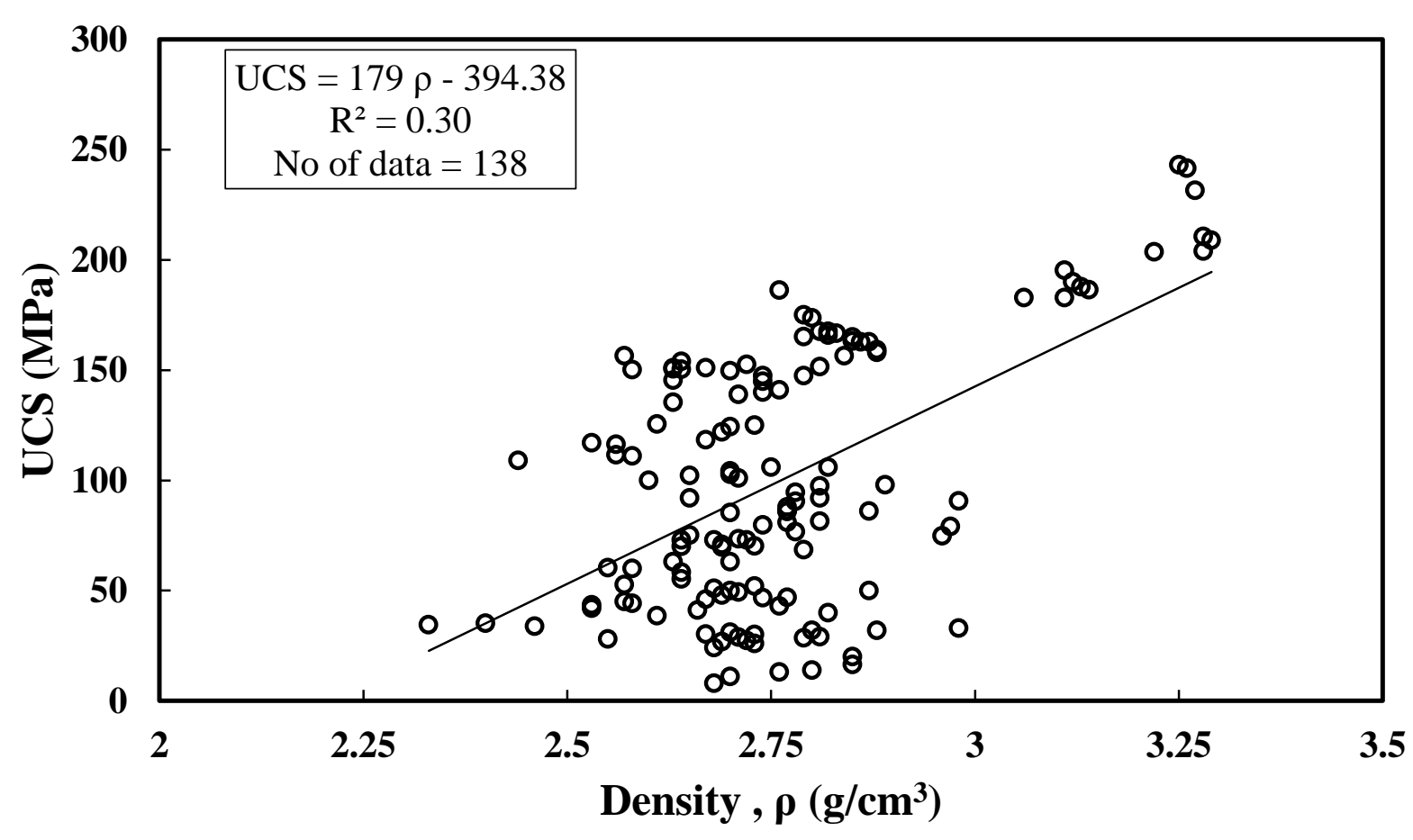

Fig. 2 linear variation between density ( $\rho)$ and UCS (MPa) 


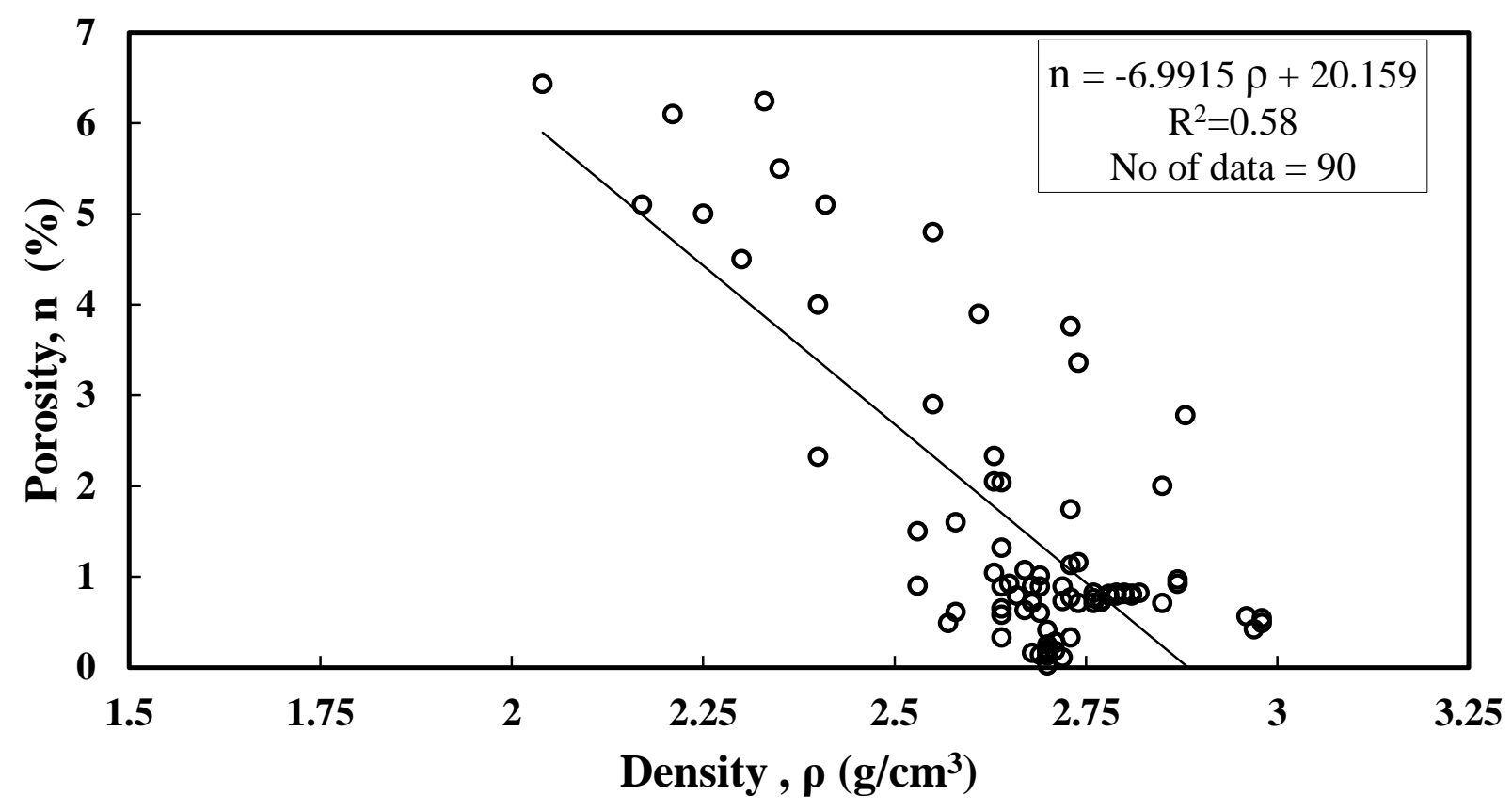

Fig. 3 linear variation between density ( $\rho$ ) and Porosity, n (\%)

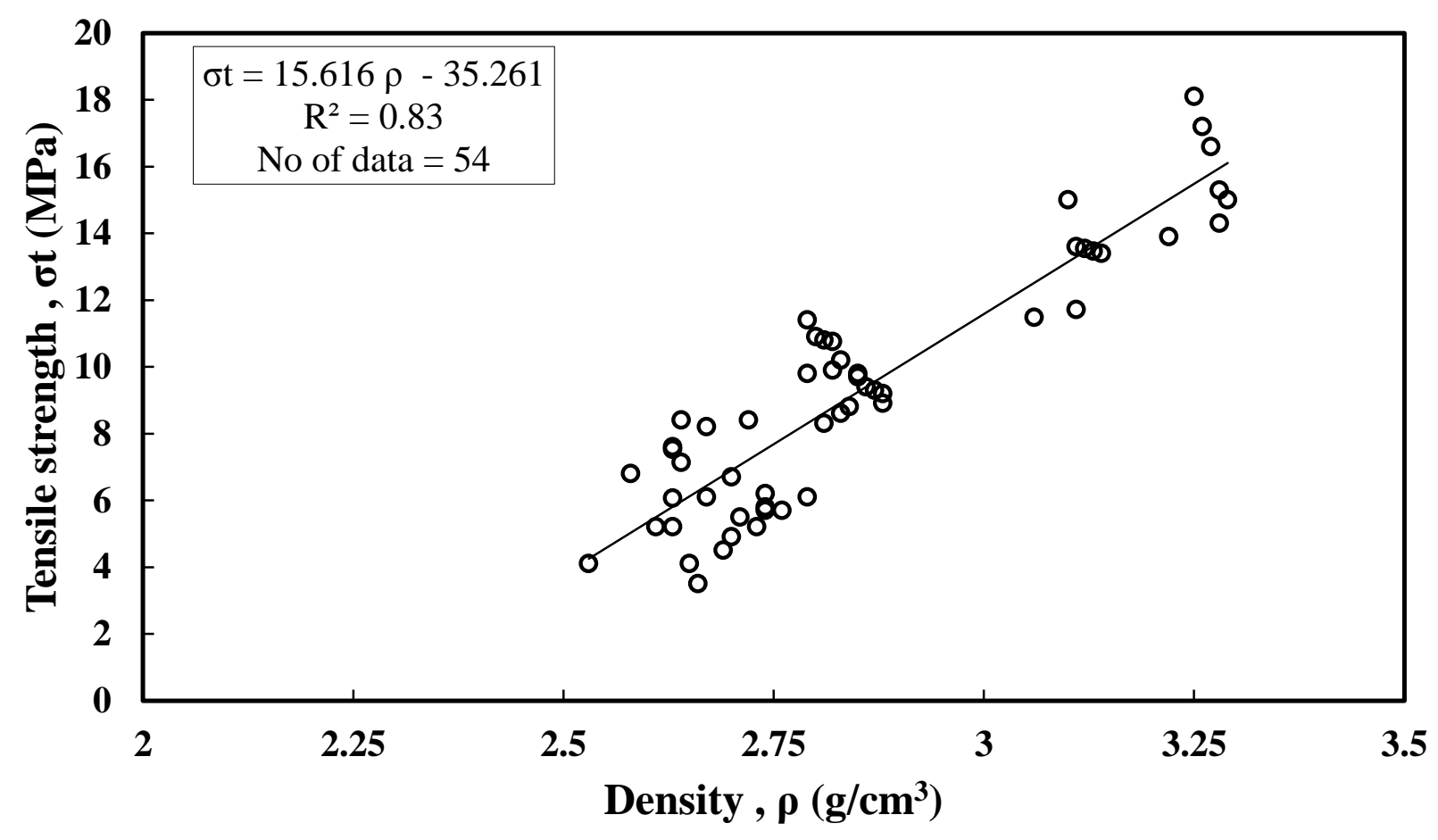

Fig. 4 linear variation between density $(\rho)$ and Tensile strength, $\sigma_{t}(\mathrm{MPa})$ 


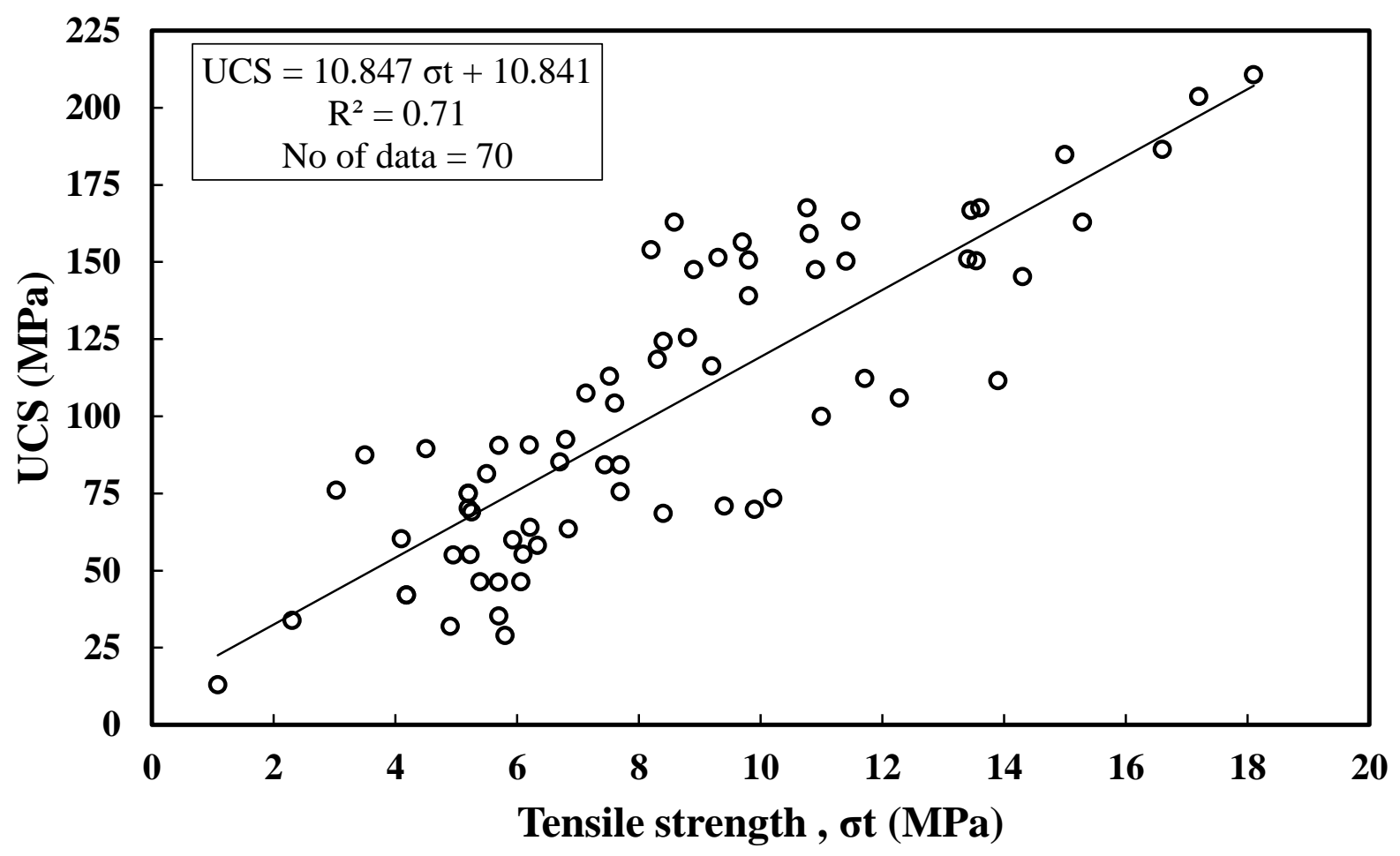

Fig. 5 linear variation between Tensile strength, $\sigma_{\mathrm{t}}(\mathrm{MPa})$ and UCS (MPa)

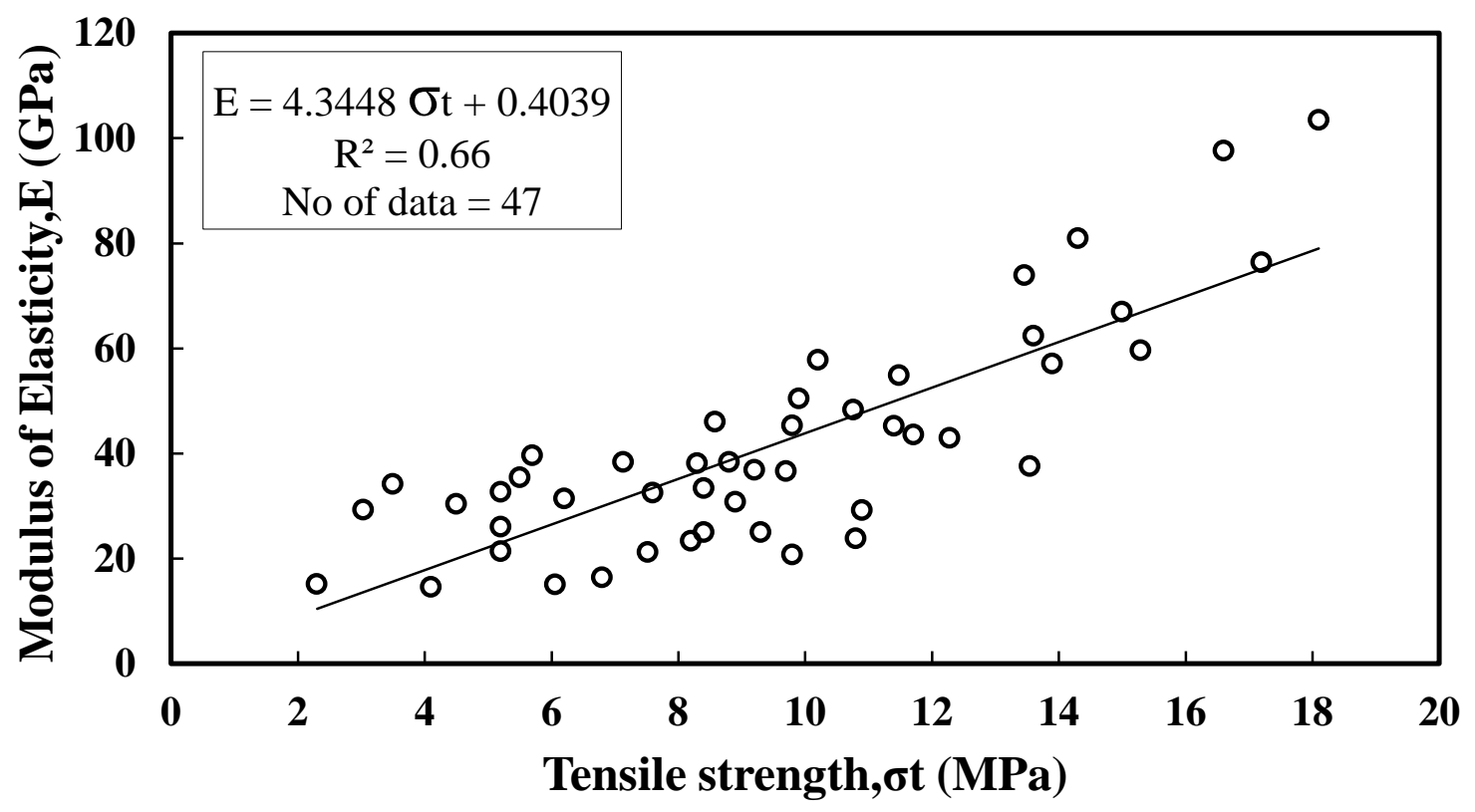

Fig. 6 linear variation between Tensile strength, $\sigma_{t}(\mathrm{MPa})$ and Young's modulus,E (GPa) 


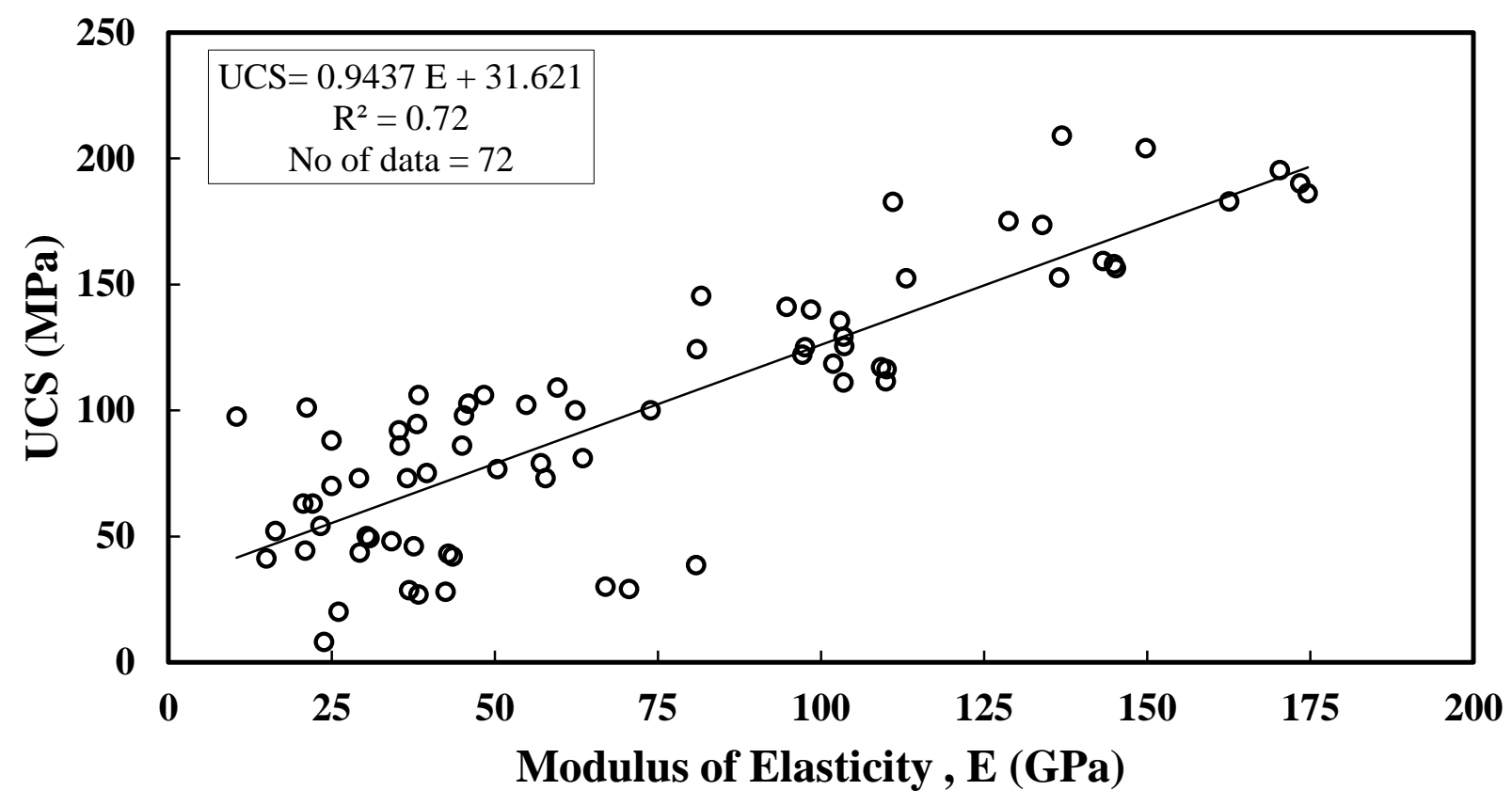

Fig. 7 linear variation between Young's modulus, E (GPa) and UCS (MPa)

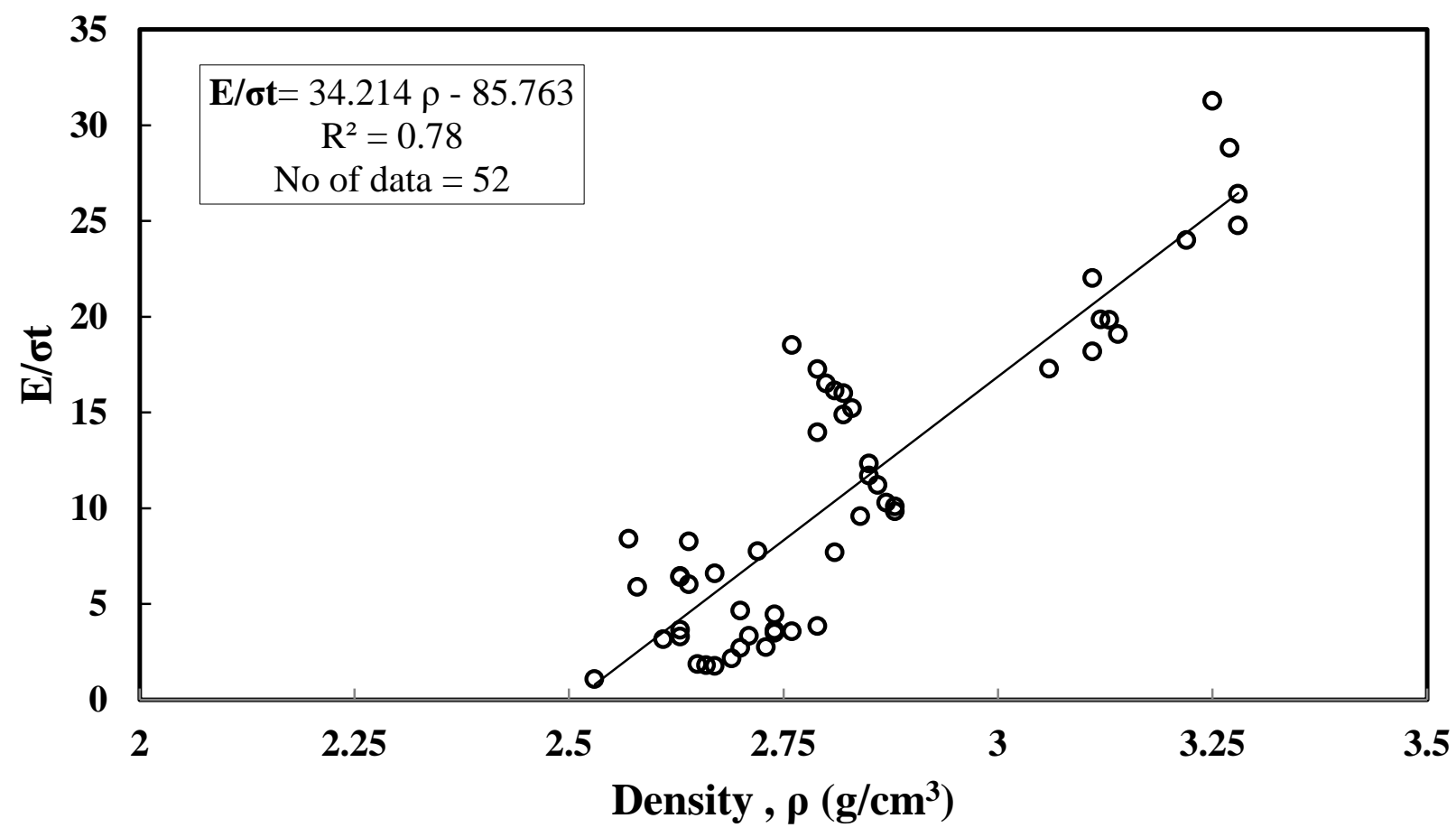

Fig. 8 linear variation between Density, $\rho\left(\mathrm{g} / \mathrm{cm}^{3}\right)$ and $\mathrm{E} / \sigma_{\mathrm{t}}$ 


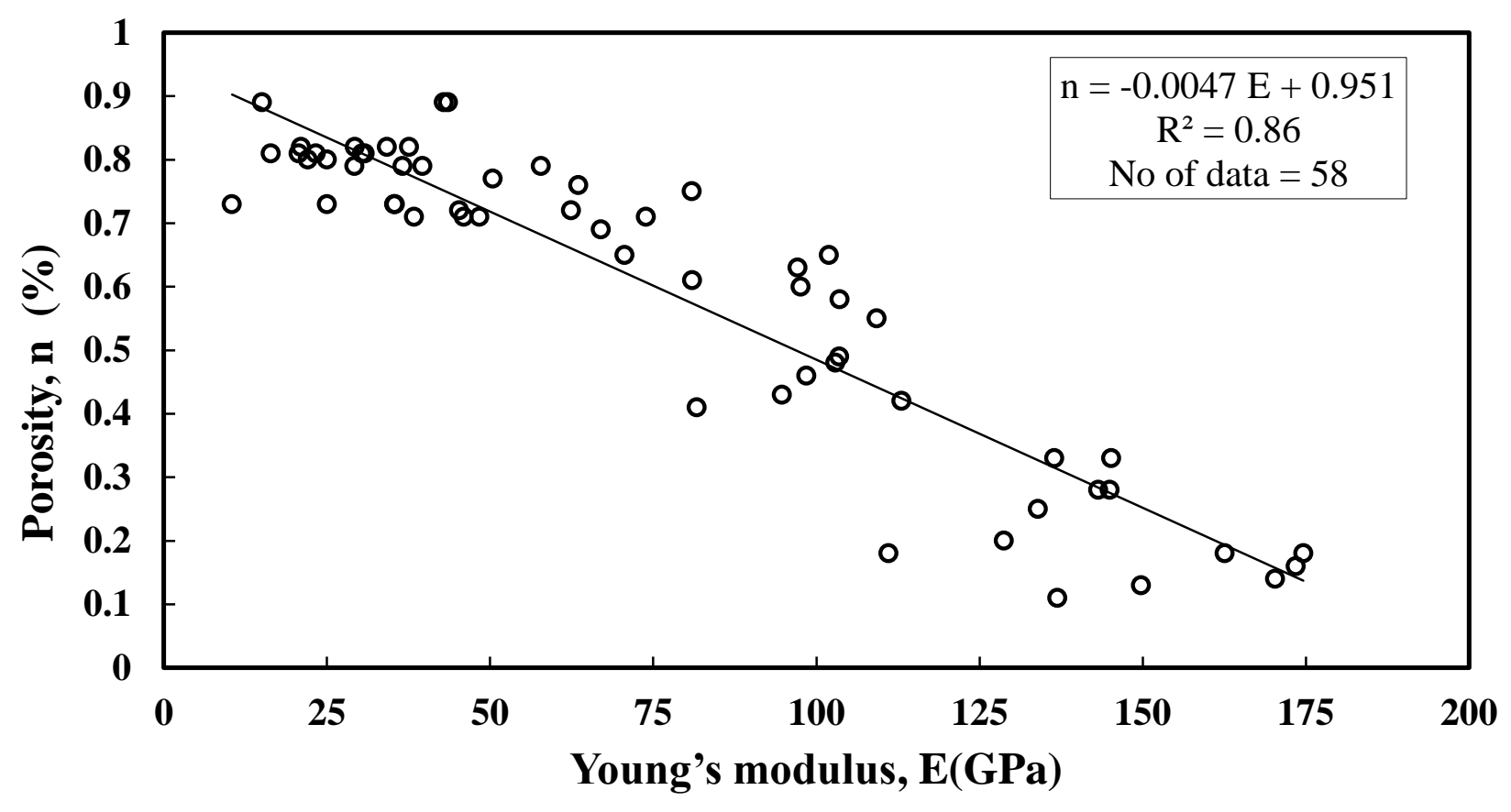

Fig. 9 linear variation between Young's modulus, E (GPa) and Porosity, n (\%)

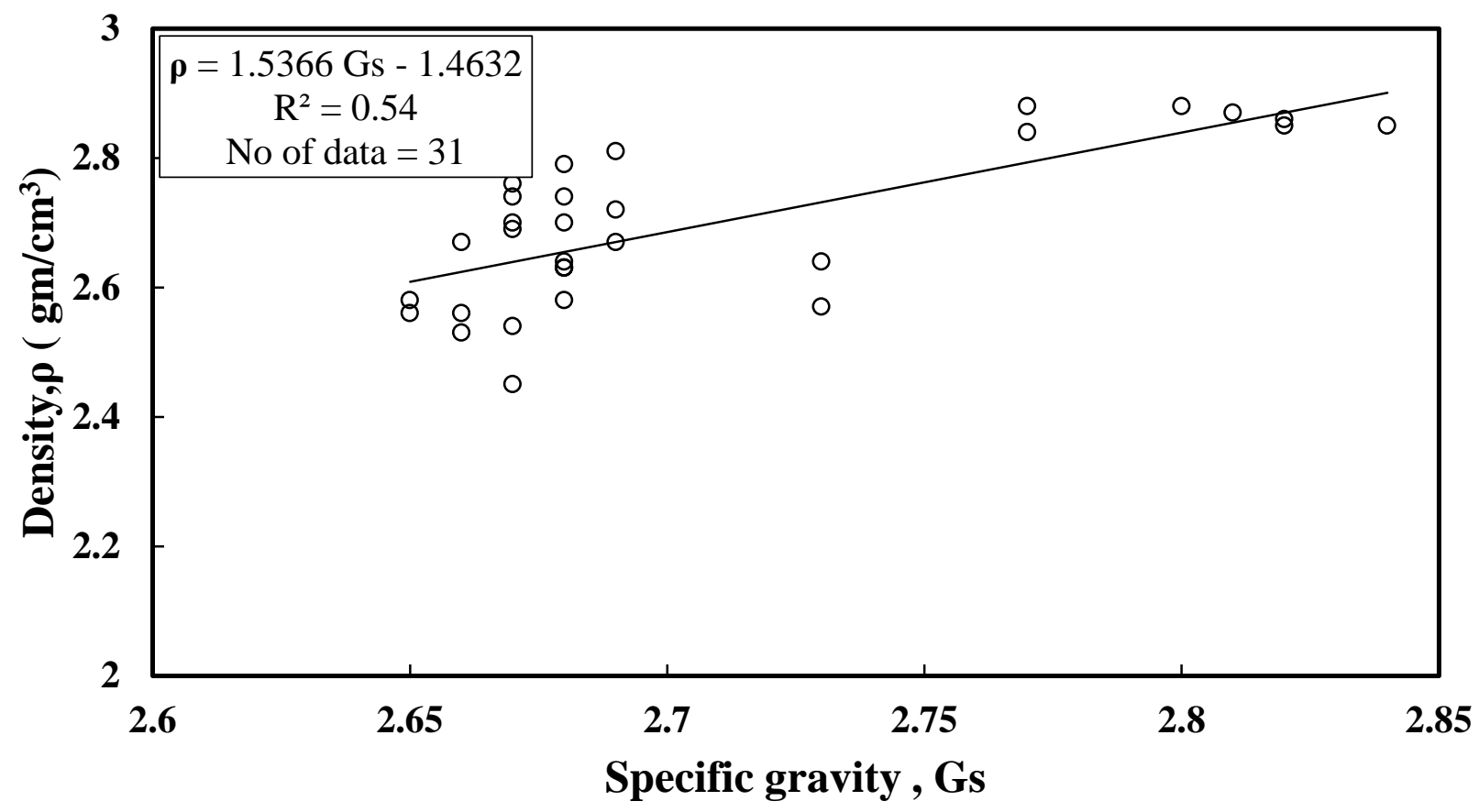

Fig. 10 linear variation between Specific gravity, Gs, and density, $\rho\left(\mathrm{gm} / \mathrm{cm}^{3}\right)$ 


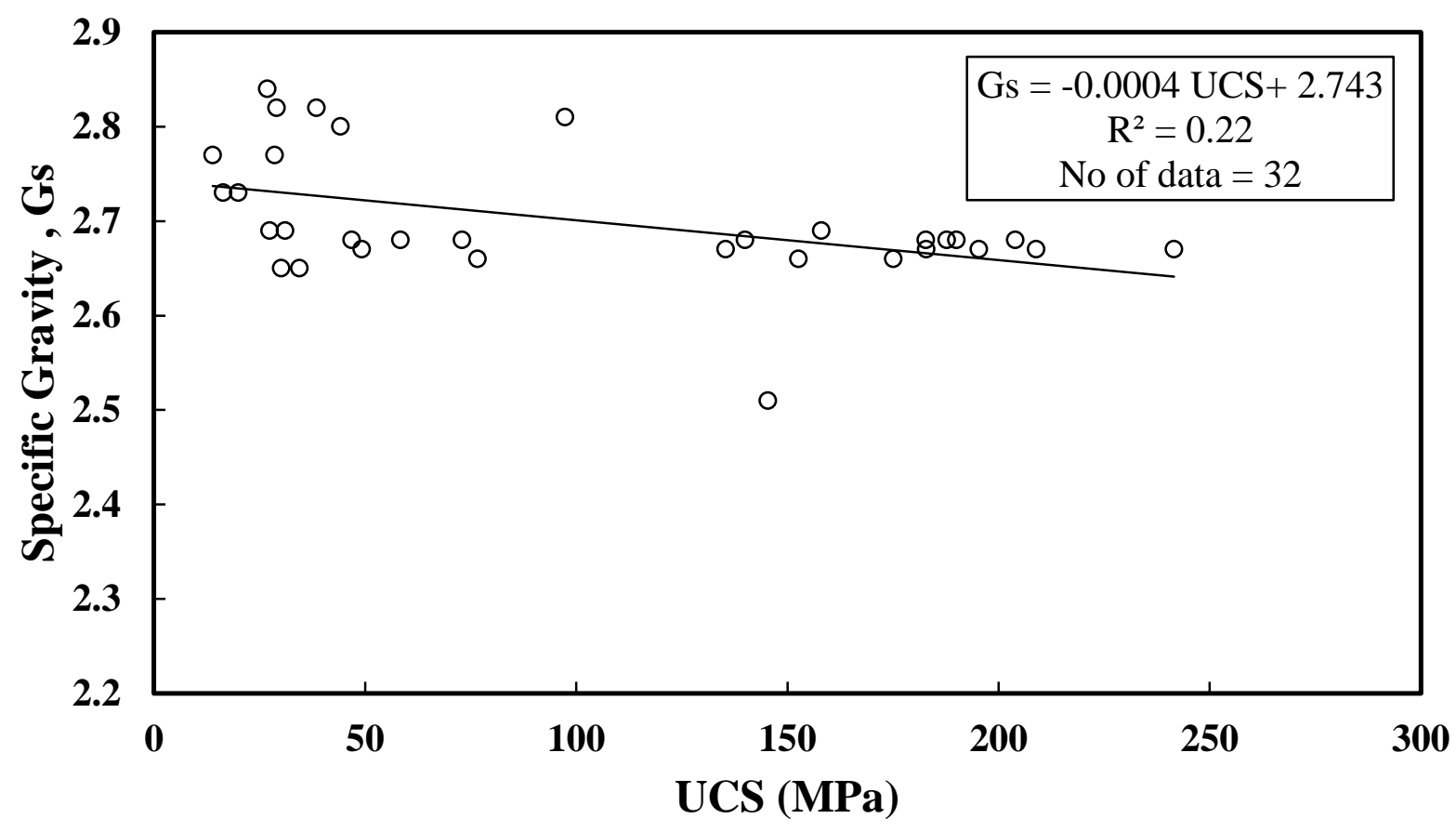

Fig. 11 linear variation between UCS (MPa) and Specific Gravity, Gs

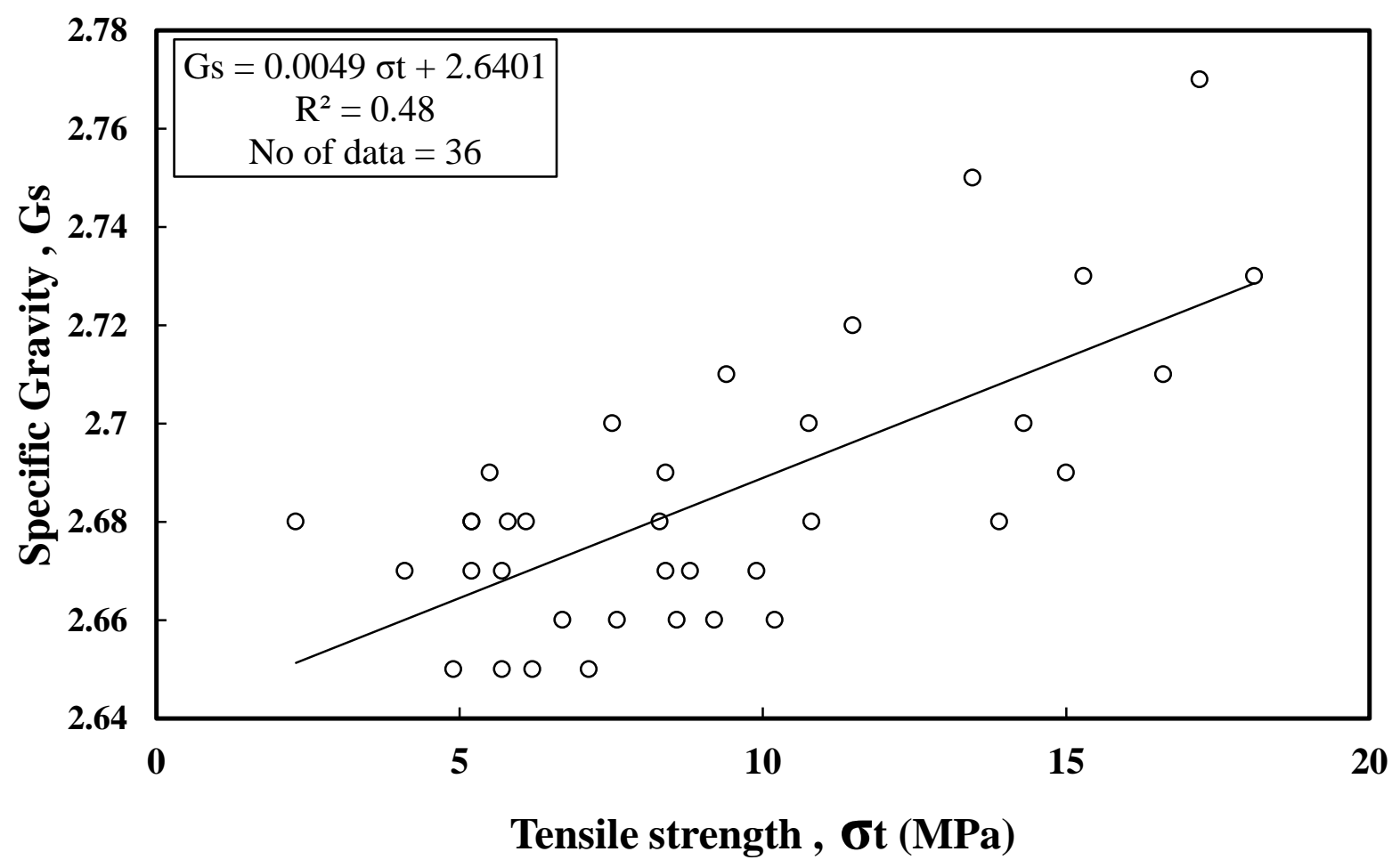

Fig. 12 linear variation between Tensile strength, ot (MPa) and Specific Gravity, Gs 


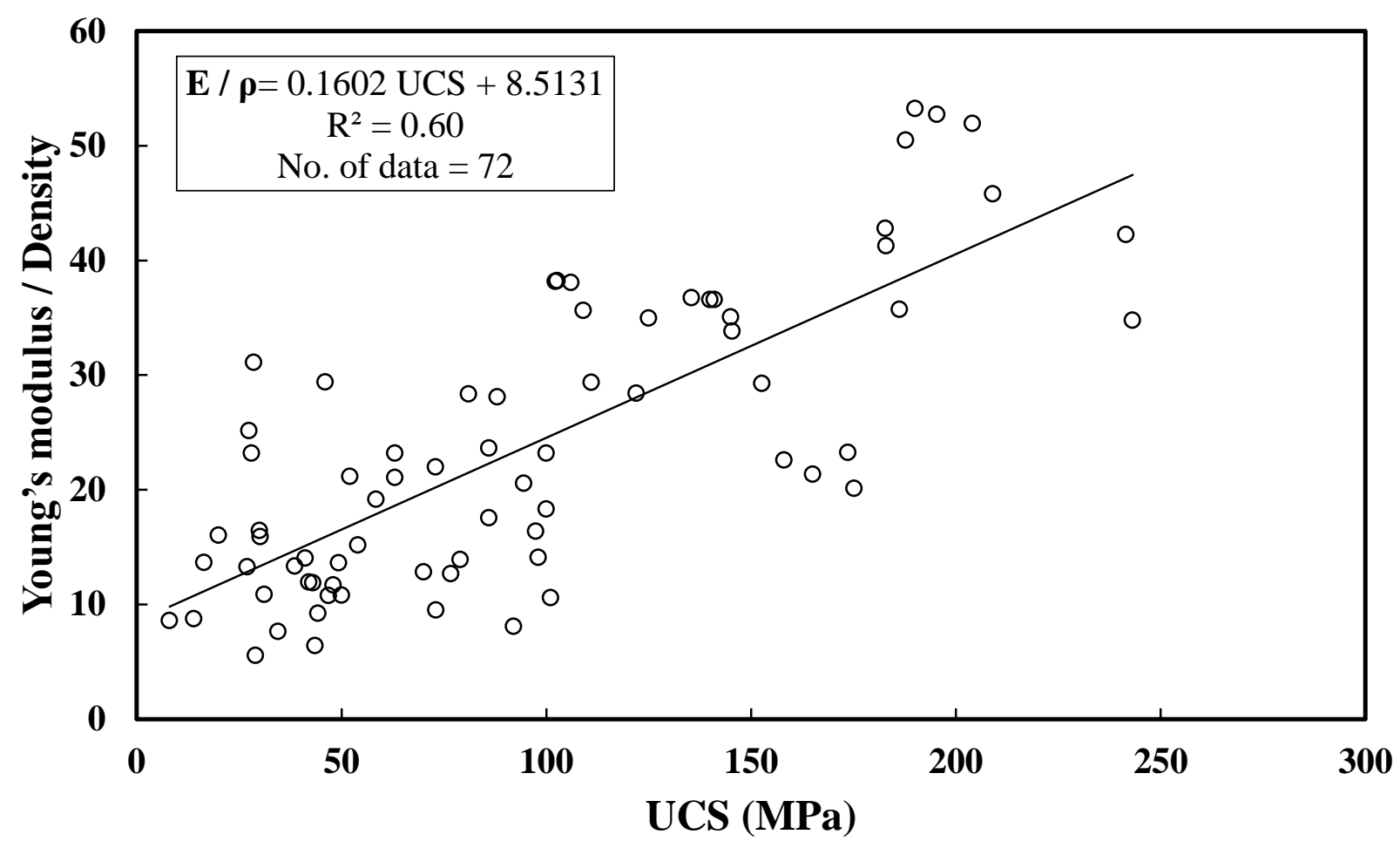

Fig. 13 linear variation between UCS (MPa) and Young's modulus / Density

\section{Conclusions}

This study aimed to investigate the relationship between the physical and mechanical properties of metamorphic rocks. The statistical analyses of metamorphic rocks were studied. Correlation between geotechnical properties of metamorphic rocks was examined based on data was collected from literature; the following conclusions can be drawn:

1. The best linear relationships have been found between Young's modulus with Porosity with $\mathrm{R}^{2}=0.86$.

2. Density with Tensile strength has a linear correlation with $\mathrm{R}^{2}=0.83$.

3. UCS and Specific Gravity has a weak linear correlation with $\mathrm{R}^{2}=0.22$.

4. Linear correlation between Density and UCS with $\mathrm{R}^{2}=0.30$.

5. It would be better for future to work on the relationships between UCS with Specific Gravity and Density with UCS. 


\section{References}

Al-Juboury, A. I., \& Al-Hadidy, A. H. (2009). Petrology and depositional evolution of the Paleozoic rocks of Iraq. Marine and Petroleum Geology, 26(2), 208-231.

Barros, R. S., Oliveira, D. V., Varum, H., Alves, C. A., \& Camões, A. (2014). Experimental characterization of physical and mechanical properties of schist from Portugal. Construction and Building Materials, 50, 617-630.

Benayad, S., Park, Y.-S., Chaouchi, R., \& Kherfi, N. (2013). Unconventional resources in Algeria: appraisal result from the Hamra Quartzite reservoir. Geosciences Journal, 17(3), 313-327.

Chen, Y.-F., Wei, K., Liu, W., Hu, S.-H., Hu, R., \& Zhou, C.-B. (2016). Experimental characterization and micromechanical modeling of anisotropic slates. Rock Mechanics and Rock Engineering, 49(9), 3541-3557.

El-Hamid, M. A., Draz, W., Ismael, A., Gouda, M., \& Sleem, S. (2015). Effect of Petrographical Characteristics on the Engineering Properties of Some Egyptian Ornamental Stones. International Journal of Scientific \& Engineering Research, 6(7).

Fereidooni, D. (2016). Determination of the geotechnical characteristics of Hornfelsic rocks with a particular emphasis on the correlation between physical and mechanical properties. Rock Mechanics and Rock Engineering, 49(7), 2595-2608.

Gegenhuber, N. (2016). Interpretation of elastic properties for magmatic and metamorphic rock types. International Journal of Rock Mechanics and Mining Sciences (88), 44-48.

Gholami, R., \& Rasouli, V. (2014). Mechanical and elastic properties of transversely isotropic slate. Rock Mechanics and Rock Engineering, 47(5), 1763-1773.

Kahraman, S., Fener, M., \& Kozman, E. (2012). Predicting the compressive and tensile strength of rocks from indentation hardness index. Journal of the Southern African Institute of Mining and Metallurgy, 112(5), 331-339.

Khanlari, G.-R., Heidari, M., Sepahigero, A.-A., \& Fereidooni, D. (2014). Quantification of strength anisotropy of metamorphic rocks of the Hamedan province, Iran, as determined from a cylindrical punch, point load, and Brazilian tests. Engineering Geology, 169, 80-90.

Mishra, S., Chakraborty, T., \& Matsagar, V. (2017). Dynamic Characterization of Himalayan Quartzite Using SHPB. Procedia engineering, 191, 2-9. 
Motra, H. B., \& Zertani, S. (2017). Influence of loading and heating processes on elastic and geomechanical properties of eclogites and granulites. Journal of Rock Mechanics and Geotechnical Engineering.

Mustafa, S., Khan, M. A., Khan, M. R., Hameed, F., Mughal, M. S., Asghar, A., \& Niaz, A. (2015). Geotechnical study of marble, schist, and granite as dimension stone: a case study from parts of Lesser Himalaya, Neelum Valley Area, Azad Kashmir, Pakistan. Bulletin of engineering geology and the environment, 74(4), 1475-1487.

Owaid, M. N., \& Abed, I. A. (2015). Mineral analysis of phosphate rock as Iraqi raw fertilizer. International Journal of Environment, 4(2), 413-415.

Özbek, A., Gül, M., Karacan, E., \& Alca, Ö. (2018). Anisotropy effect on strengths of metamorphic rocks. Journal of Rock Mechanics and Geotechnical Engineering.

Ozcelik, Y. (2011). Predicting Los Angeles abrasion of rocks from some physical and mechanical properties. Scientific Research and Essays, 6(7), 1612-1619.

Perras, M. A., \& Diederichs, M. S. (2014). A review of the tensile strength of rock: concepts and testing. Geotechnical and geological engineering, 32(2), 525-546.

Siegesmund, S., \& Dürrast, H. (2011). Physical and mechanical properties of rocks Stone in architecture (pp. 97-225): Springer.

Singh, T., Jain, A., \& Rao, K. (2017). Physico-mechanical Behaviour of Metamorphic Rocks in Rohtang Tunnel, Himachal Pradesh, India. Procedia engineering, 191, 419-425.

Su, O., \& Momayez, M. (2017). Indirect estimation of electrical resistivity by abrasion and physicomechanical properties of rocks. Journal of Applied Geophysics, 143, 23-30.

Tandon, R. S., \& Gupta, V. (2013). The control of mineral constituents and textural characteristics on the petrophysical \& mechanical (PM) properties of different rocks of the Himalaya. Engineering Geology, 153, 125-143. 